\title{
Kontribusi Model Pembelajaran Web Centric Cource dan Self-Efficacy Komputer terhadap Prestasi Belajar Siswa Paket Keahlian Rekayasa Perangkat Lunak di SMK
}

\author{
Mohammad Mahmudi ${ }^{1}$, Djoko Kustono ${ }^{2}$, Maftuchin Romlie ${ }^{2}$ \\ ${ }^{1}$ Pendidikan Kejuruan-Universitas Negeri Malang \\ ${ }^{2}$ Teknik Mesin-Universitas Negeri Malang
}

\section{INFO ARTIKEL \\ Riwayat Artikel: \\ Diterima: 10-05-2019 \\ Disetujui: 16-12-2019

\begin{abstract}
Kata kunci:
web centric cource; self-efficacy komputer; student achievement; web centric cource; self-efficacy komputer; prestasi belajar siswa
\end{abstract}

\section{Alamat Korespondensi:}

Mohammad Mahmudi Pendidikan Kejuruan Universitas Negeri Malang

Jalan Semarang 5 Malang E-mail: republikendok@gmail.ac.id

\begin{abstract}
This study aims to determine (1) significant influence of students learning motivation with Basic Programming learning outcomes, (2) significant effect of students computer self-efficacy with Basic Programming learning outcomes, (3) Significant differences in Basic Programming learning outcomes between groups of students who are taught with a web centric course are equipped with modules with groups of students who are taught with conventional models with modules. This study employed Nonequievalent Control Group Design with the consideration that the choosing of experimental and control group could not be determined by individual random sampling but it was done through assignment random sampling to the ten graders of software engineering department. Test instrument was used to measure computer self-efficacy and students' motivation. The data analysis techniques used oneway covariance analysis with two covariates. The results of the study revealed: (1) there is no significant effect of students' learning motivation with Basic Programming learning result, this means less learning motivation in determining the role of treatment and improvement of learning outcomes, (2) there is a significant influence of Self Efficacy Computer students with Basic Programming learning outcomes, and (3) there is a significant difference in Basic Programming learning outcomes between groups of students taught with web centric courses equipped with modules with groups of students taught with conventional learning models equipped with modules.
\end{abstract}

\begin{abstract}
Abstrak: Penelitian ini bertujuan untuk mengetahui (1) pengaruh yang signifikan motivasi belajar siswa dengan hasil belajar Pemrograman Dasar, (2) pengaruh yang signifikan self-efficacy komputer siswa dengan hasil belajar Pemrograman Dasar, dan (3) perbedaan yang signifikan hasil belajar Pemrograman Dasar antara kelompok siswa yang diajar dengan web centric course dilengkapi modul dengan kelompok siswa yang diajar dengan model konvensional dilengkapi modul. Penelitian ini menggunakan rancangan Nonequievalent Control Group Design dengan pertimbangan bahwa dalam penentuan kelompok eksperimen dan kelompok kontrol tidak dapat dilakukan dengan random acak individu, tetapi dilakukan dengan random kelompok (assignment random sampling) yaitu pada kelas X paket keahlian Rekayasa Perangkat Lunak. Teknik analisis data menggunakan analisis covariance satu jalan dengan dua covariate. Hasil penelitian menunjukkan (1) tidak ada pengaruh yang signifikan motivasi belajar siswa dengan hasil belajar Pemrograman Dasar, ini berarti motivasi belajar kurang berperan dalam menentukan pemberian perlakukan dan peningkatan hasil belajar, (2) ada pengaruh yang signifikan Self Efficacy Komputer siswa dengan hasil belajar Pemrograman Dasar, dan (3) ada perbedaan hasil belajar Pemrograman Dasar yang signifikan antara kelompok siswa yang diajar dengan web centric course dilengkapi modul dengan kelompok siswa yang diajar dengan model pembelajaran konvensional dilengkapi modul.
\end{abstract}


Potensi yang dimiliki teknologi komunikasi tidak saja meningkatkan efisiensi dan keefektifan serta keluwesan proses pembelajaran, tetapi juga berdampak pada pengembangan materi, pergeseran peran guru dan semakin berkembangnya otonomi siswa. Pembelajaran yang berpusat pada guru berubah menjadi pembelajaran yang berpusat pada siswa. Perubahan paradikma ini, merupakan suatu upaya penting untuk mengoptimalkan proses pembelajaran yang menumbuhkan keaktifan siswa dalam belajar. Tujuan pendidikan nasional adalah tujuan pendidikan yang ingin dicapai pada tingkat nasional, sebagaimana tercantum dalam Undang-Undang RI No.2 Tahun 1989 tentang Sistem Pendidikan Nasional pada Bab II, Pasal 4, yang berbunyi: "Pendidikan Nasional bertujuan mencerdaskan kehidupan bangsa dan mengembangkan manusia Indonesia seutuhnya, yaitu manusia yang beriman dan bertakwa terhadap Tuhan Yang Maha Esa dan berbudi pekerti luhur, memiliki pengetahuan dan keterampilan, kesehatan jasmani dan rohani, kepribadian yang mantap dan mandiri serta rasa tanggung jawab kemasyarakatan dan kebangsaaan".

Motivasi belajar siswa dapat menjadi lemah. Lemahnya motivasi atau tiadanya motivasi belajar akan melemahkan kegiatan, sehingga mutu prestasi belajar akan rendah. Oleh karena itu, mutu prestasi belajar pada siswa perlu diperkuat terusmenerus. Dengan tujuan agar siswa memiliki motivasi belajar yang kuat, sehingga prestasi belajar yang diraihnya dapat optimal (Dimyati \& Mudjiono, 2006). Pengembangan model pembelajaran berbasis internet perlu dirancang secara cermat sesuai tujuan yang diinginkan. Menurut pendapat (Azwar, 2013) ada tiga kemungkinan dalam pengembangan model pembelajaran berbasis internet, yaitu web course, web centric course, dan web enhanced course. Web centric course dikenal juga dengan istilah blended (hybrid course) adalah model pembelajaran yang mencakup komponen online maupun tatap muka, sementara model pembelajaran tatap muka dan online saja membatasi program pembelajaran (Singh, 2003).

Faktor lain yang berpengaruh terhadap keberhasilan dalam pembelajaran online adalah self-efficacy kemampuan komputer. (Cassidy \& Eachus, 2002) melaporkan bahwa self-efficacy kemampuan komputer merupakan faktor penting untuk frekuensi dan keberhasilan dalam penggunaan komputer. Menurut (Bandura, 1994), orang yang memiliki self-efficacy yang tinggi pula dalam menjalani dan menyelesaikan kesulitan-kesulitan yang dihadapinya. Bagaimanapun, pembelajaran berbasis internet apabila diakses secara benar dan luas diharapkan efektif tidak hanya didalam mengoptimalkan pembelajaran, tetapi juga didalam mengurangi biaya, dan meningkatkan akses dan kepuasan siswa, yang pada akhirnya hasil belajar siswa menjadi prioritas dalam meningkatkan pemanfaatannya. Sejauh mana pemilihan model pembelajaran berbasis internet web centric course, self-efficacy komputer dan motivasi belajar berpengaruh terhadap hasil belajar siswa khususnya hasil belajar mata pelajaran pemrograman dasar sangat menarik untuk diteliti dan menjadi tujuan utama penelitian ini.

Sesuai dengan penelitian-penelitian sebelumnya yang menyatakan bahwa pembelajaran berbasis web dapat mempengaruhi motivasi belajar mahasiswa Teknologi Pendidikan, (Hermawan, 2013). Penelitian lain (Nurhikmah, Hakim, Muin, Hartoto, \& Ramli 2010) hasil belajar mahasiswa yang memiliki self-efficacy kemampuan komputer tinggi memberikan pengaruh yang lebih baik dibandingkan dengan mahasiswa yang memiliki self-efficacy kemampuan komputer rendah. Serta terdapat pengaruh yang positif self-efficacy dan motivasi berprestasi secara bersama terhadap kemandirian belajar mata pelajaran K3 (Keselamatan dan Kesehatan Kerja) di SMK N 2 Depok dalam (Widiyanto, 2013).

\section{METODE}

Penelitian ini dilaksanakan untuk menguji signifikasi pengaruh model pembelajaran web centric cource, motivasi belajar dan self-efficacy sebagai variable bebas terhadap hasil belajar siswa sebagai variabel terikat. Pengaruh tersebut dapat dilihat dari akibat yang ditimbulkan (adanya perbedaan rata-rata perolahan hasil belajar) oleh adanya manipulasi variabel bebas dalam kelompok eksperimen (manipulasi dilakukan dengan memberi perlakuan berupa penggunan model pembelajaran web centric cource dilengakapi modul pemrograman $\mathrm{C}++$ ) dibandingkan dengan perolehan hasil belajar siswa kelompok kontrol yang diberi perlakuan berupa pembelajaran konvesional dilengkapi modul pemrograman $\mathrm{C}++$. Modul dalam penelitian ini berfungsi sebagai bahan belajar yang digunakan dalam pembelajaran. Dengan modul siswa dapat belajar lebih terarah, sistematis, dan madiri. Bagi guru modul berfungsi sebagai alat bantu dalam menyampaikan materi yang dipelajari. Modul pada kelompok eksperimen dan kelompok kontrol dibuat sama, hal ini dikarenakan dalam pembelajaran web centric cource maupun konvensional siswa diberikan materi yang sama, tetapi berbeda perlakuan.

Penelitian ini dilaksanakan dengan rancangan kuasi eksperimen. Penggunaan rancangan ini dimaksudkan untuk mengungkap hubungan sebab akibat dengan cara melibatkan kelompok kontrol disamping kelompok eksperimen (Anwar Sanusi, 2012). Dari pendapat Campbell dan Stanley (1996), Borg dan Gall (1983), Moore (1983), dan Gay (1987) dapat disimpulkan bahwa peneletian quasi eksperimen berupa (1) memanipulasi satu atau lebih variabel bebas secara sistematis dan logis, (2) mengamati pengaruhnya terhadap variabel tergantung, (3) memperkecil kemungkinan terjadinya kontaminasi pengaruh variabel yang lain (baik variabel moderator ataupun kontrol), dan (4) dilakukannya strategi sampling random assignment terhadap kelompok (kelas) yang sudah ada dalam menentukan kelompok kontrol dan kelompok eksperimen (Pratiwi et al., 2010).

Penelitian ini menggunakan rancangan Nonequievalent Control Group Design dengan pertimbangan bahwa dalam penentuan kelompok eksperimen dan kelompok kontrol tidak dapat dilakukan dengan random acak individu, tetapi dilakukan dengan random kelompok (assignment random sampling) yaitu pada kelas X RPL B dan X RPL C. Cara ini ditempuh berdasarkan pertimbangan bahwa tidak dimungkinkannya dilakukan pemilihan kelompok eksperimen dan kelompok kontrol dengan random terhadap subjek dalam penelitian. 


\section{Variabel Penelitian \\ Variabel $\mathrm{X}_{1}$ : Model Pembelajaran Web Centric Course}

Rancangan proses pembelajaran web centric course menggunakan aplikasi media pembelajaran yaitu edmodo yang merupakan sebuah aplikasi yang dikembangkan seperti jejaring sosial ysng didesain khusus untuk dunia pendidikan. Edmodo memuat fasilitas bagi guru untuk pemberian tugas, penilaian, polling, agenda, berbagi file dan catatan, chatting antar siswa dengan siswa, chatting antara siswa dengan guru, bahkan dengan orangtua siswa sehingga edmodo adalah aplikasi pembelajaran yang dapat dipergunakan sebagai media pembelajaran secara online. Aplikasi edmodo dapat diinstall dalam perangkat komputer maupun smartphone dimana hampir setiap siswa sudah memiliki media tersebut.

\section{Variabel $\mathrm{X}_{2}$ : Self-Efficacy terhadap Komputer}

Untuk mengukur Self-Efficacy komputer siswa mengadopsi instrumen CSE (Komputer Self-Efficacy) yang dikembangkan oleh (Durndell et al., 2000). CSE memiliki 29 butir dimana setiap item diawali dengan kata "Saya merasa yakin". Lima skala Likert digunakan untuk menyatakan respon dari subjek tentang item-item yang diajukan. Angka 1 berarti sangat tidak setuju, angka 2 berarti tidak setuju, angka 3 ragu-ragu, angka 4 berarti setuju, dan angka 5 berarti sangat setuju. Skor total untuk CSE berkisar antara 29 sampai dengan 145 Skor tertinggi mengidentifikasi sebuah derajat keyakinan yang tinggi pada kemampuan subyek untuk menggunakan komputer dan skor yang rendah mengidentifikasikan sebaliknya (Sam et al., 2005).

Butir-butir pada The Komputer Self-Eficacy Scale (CSE) yang dikembangkan oleh (Durndell et al., 2000) diperoleh dari artikel (Sam et al., 2005) yang dimuat dalam jurnal Education Technology \& Society, 8(4) 205-219. Butir-butir yang dimuat dalam artikel tersebut berbahasa Inggris. Kemudian butir-butir tersebut diterjemahkan kedalam bahasa Indonesia.

\section{Variabel $\mathrm{X}_{3}$ : Motivasi Belajar Siswa}

Motivasi belajar siswa meliputi motivasi dalam diri siswa/motivasi intrinsik dalam diri masing-masing siswa dan motivasi ektrinsik yang berasal dari ruang luar diri siswa. Berikut pembelajaran dari instrumen motivasi belajar (Tabel 1).

Tabel 1. Kisi-kisi Instrumen Penelitian Variabel Motivasi Belajar

\begin{tabular}{clc}
\hline Sub Variabel & \multicolumn{1}{c}{ Indikator } & \multicolumn{1}{c}{ Nomor Butir } \\
\hline \multirow{2}{*}{ Motivasi } & Adanya hasrat dan keinginan berhasil & $1,2,4,5,6,7,8$ \\
Intrinsik & Adanya dorongan dan kebutuhan dalam belajar & $9,10,11,12,13,14,15,16$ \\
& Adanya harapan dan cita-cita masa depan & $17,18,19,20,21,22,23,24$ \\
\hline \multirow{2}{*}{ Motivasi } & Adanya penghargaan dalam belajar & $25,26,27,28,29,30,31,32$ \\
Ektrinsik & Adanya keinginan yang menarik dalam belajar & $33,34,35,36,37,38,39,40$ \\
& Adanya lingkungan belajar yang kondusif & $41,42,43,44,45,46,47,48$ \\
\hline
\end{tabular}

Pernyataan-pernyataan dalam angket tersebut berdasarkan skala likert. Setiap pernyataan dari masing-masing butir memiliki lima alternatif jawaban dan skor jawaban pada pernyataan yang dijabarkan pada tabel 2.

Tabel 2. Variabel Y: Prestasi Belajar Siswa

\begin{tabular}{lc}
\hline Alternatif Jawaban & Skor Jawaban \\
\hline Sangat setuju & 5 \\
Setuju & 4 \\
Netral & 3 \\
Tidak setuju & 2 \\
Sangat tidak setuju & 1 \\
\hline
\end{tabular}

Prestasi belajar siswa diukur berdasarkan kriteria yang ditetapkan oleh penilai berupa rerata nilai akhir proses pembelajaran, baik pada kelas eksperimen yang menggunakan metode pembelajaran web centric course dan kelas kontrol yang menggunakan metode pembelajaran konvensional.

\section{Populasi dan Sample}

Populasi dalam penelitian ini adalah Sekolah Menegah Kejuruan Negeri 4 Malang Bidang Studi Keahlian Teknologi Informasi dan Komunikasi yakni paket keahlian Rekayasa Perangkat Lunak. Dengan rincian yang ditunjukkan pada tabel 3. 
Tabel 3. Penelitian Populasi Siswa

\begin{tabular}{|c|c|c|c|}
\hline No & Paket Keahlian & Kelas & Jumlah Siswa \\
\hline \multirow[t]{5}{*}{1} & Rekayasa Perangkat Lunak & X RPL A & 33 \\
\hline & & X RPL B & 33 \\
\hline & & X RPL C & 33 \\
\hline & & X RPL D & 32 \\
\hline & Jumlah & 131 & \\
\hline
\end{tabular}

Pada penelitian ini teknik pengambilan sampelnya menggunakan random assignment. Penggunaan random asignment ditempuh dengan berdasarkan pertimbangan bahwa tidak memungkinkannya dilakukan pemilihan kelompok eksperimen dan kelompok kontrol dengan random terhadap subjek dalam penelitian ini (Pratiwi et al., 2010). Sehingga jumlah siswa yang dijadikan sebagai subjek penelitian yang eksperimen sejumlah 66 siswa yang terbagi dalam dua kelas yaitu XI RPL B dan XI RPL C seperti yang disajikan pada tabel 4.

Tabel 4. Sampel Penelitian Siswa

\begin{tabular}{clc}
\hline No & Kelas & Jumlah Siswa \\
\hline 1 & X RPL B & 33 \\
2 & X RPL C & 33 \\
& Jumlah & 66 \\
\hline
\end{tabular}

Sebelum menetapkan kelompok, perlakuan, dan kontrol terlebih dahulu dilakukan tes kemampuan awal tiap kelompok untuk memastikan bahwa kelas/kelompok tersebut mempunyai kemampuan awal yang sepadan sebelum perlakuan diberikan. Nilai yang digunakan adalah nilai pre test pada kompetensi dasar Operasi Aritmatika dan Logika, Array, operasi String dan Konversi Data, Pointer. Berdasarkan pemilihan kelas/kelompok eksperimen dan kelompok kontrol sebagaimana yang dijelaskan pada tabel 5 .

Tabel 5. Penetapan Kelas/Kelompok Eksperimen dan Kelompok Kontrol

\begin{tabular}{lll}
\hline No & Kelas & Perlakuan \\
\hline 1 & X RPL B & $\begin{array}{l}\text { Kelas perlakuan yang memperoleh model pembelajaran berbasis web } \\
\text { centric course. }\end{array}$ \\
\hline 2 & X RPL C & Kelas control yang memperoleh model pembelajaran konvensional. \\
\hline
\end{tabular}

\section{Instrumen Penelitian}

\section{Instrumen Self-efficacy Komputer Siswa}

CSE adalah skala untuk mengukur tingkat Computer Self-Efficacy yang dikembangkan oleh (Durndell et al., 2000). CSE memiliki 29 item dimana stiap item diawali denagan kata "saya merasa yakin". Lima skala Likert digunakan untuk menyatakan respons dari subjek tentang butir-butir yang diajukan. Angka 1 berarti sanagat tidak setuju, angka 2 berarti tidak setuju, angka 3 berarti ragu-ragu, angka 4 berarti setuju, dan angka 5 berarti sangat setuju. skor total untuk CSE berkisar 29 sampai dengan 145. skor tertinggi mengidentifikasikan sebuah derajat keyakinan yang tinggi pada kemampuan subjek untuk menggunakan computer dan skor yang rendah mengidentifikasikan sebaliknya (Sam et al., 2005). Berikut ini adalah Blue Print Computer Self-Efficacy Scale (Tabel 6).

Tabel 6. Blue Print Computer Self-Efficacy Scale (CSE)

\begin{tabular}{lllcc}
\hline No & Komponen Computer Self-Efficacy Scale & No. Butir & Jumlah & Total \\
\hline 1. & Computer Self-Efficacy Scale (CSE) tingkat & $1,2,4,5,6,9,12,14,1$ & 16 & $55,17 \%$ \\
& rendah (Beggining) & $5,16,17,18,20,24,2$ & & \\
& & & \\
\hline 2. & Computer Self-Efficacy Scale (CSE) tingkat & 3,28 & \\
& tinggi (Advaced) & $1,22,23,10,11,13,19,2$ & 13 & $44,83 \%$ \\
& & Total & 29 & $100 \%$ \\
\hline
\end{tabular}


Butir-butir pada The Computer Self-Efficacy Scale (CSE) yang telah dikembangkan oleh (Durndell et al., 2000) diperoleh dari artikel (Sam et al., 2005), yang dimuat dalam jurnal Education Technology \& Society , 8(4) 205-215. Butir-butir yang dimuat dalam artikel tersebut berbahasa Inggris, kemudian butir-butir tersebut diterjemahkan kedalam bahasa Indonesia.

\section{Instrumen Motivasi Belajar}

Motivasi belajar menjadi salah satu faktor yang terpenting dalam mempengaruhi hasil belajar. Dalam penelitian ini, motivasi belajar dibagi menjadi dua kelompok, yaitu motivasi belajar tinggi dan motivasi belajar rendah. Pemilihan dua kelompok ini berdasarkan skor median. Jika skor yang diperoleh siswa lebih kecil dari skor median ( $<$ median) digolongkan bermotivasi rendah, dan jika skor yang diperoleh siswa lebih besar atau sama dengan dari skor median ( $\geq$ median) digolongkan bermotivasi tinggi. Kisi-kisi pengembanngan instrumen motivasi belajar disajikan pada tabel 7.

Tabel 7. Kisi-kisi Instrumen Penelitian Variabel Motivasi Belajar

\begin{tabular}{lll}
\hline Sub Variabel & \multicolumn{1}{c}{ Indikator } & Nomor Butir \\
\hline Motivasi & 1. Adanya hasrat dan keinginan berhasil & $1,2,3,4,5,6,7,8$ \\
Instrinsik & 2. Adanya dorongan dan kebutuhan dalam belajar & $9,10,11,12,13,14,15,16$ \\
& 3. Adanya harapan dan cita-cita masa depan & $17,18,19,20,21,22,23,24$ \\
\hline Motivasi & 4. Adanya penghargaan dalam belajar & $25,26,27,28,29,30,31,32$ \\
Ekstrinsik & 5. Adanya keinginan yang menarik dalam belajar & $33,34,35,36,37,38,39,40$ \\
& 6. Adanya lingkungan belajar yang kondusif & $41,42,43,44,45,46,47,48$ \\
\hline
\end{tabular}

Sumber: (Widiarti, 2018)

\section{Kemampuan Awal dan Hasil Belajar}

Prosedur awal dalam penelitian ini ditentukan dengan cara melakukan pretest pada kompetensi dasar memahami dan menerapkan penggunaan data dalam algoritma dan konsep algoritma pemrograman, struktur algoritma percabangan dan struktur algoritma perulangan dengan enam indikator diantaranya adalah menjalankan bahasa pemrograman $\mathrm{C}++$, menjelaskan dan menerapkan struktur dasar pemrograman $\mathrm{C}++$, menerapkan tipe data, variable, konstanta dan perintah input dan output, menerapkan operator pada Pemrograman $\mathrm{C}++$, menerapkan pernyataan pemilihan dan menerapkan pernyataan perulangan.

Pengembangan instrument tes kemampuan awal mata pelajaran Pemrograman Dasar berpedoman pada kompetensi dasar "Memahami dan menerapkan penggunaan data dalam algortima dan konsep algoritma pemrograman, struktur algoritma percabangan dan struktur algoritma perulangan" dengan enam indikator diantaranya adalah menjalankan bahasa pemrograman $\mathrm{C}++$, menjelaskan dan menerapkan struktur dasar pemrograman $\mathrm{C}++$, menerapkan tipe data, variable, konstanta dan perintah input dan output, menerapkan operator pada Pemrograman $\mathrm{C}++$, menerapkan pernyataan perulangan. Instrument penelaian kemampuan awal berupa instrument penelaian diberikan dalam bentuk tes yang berupa soal objektif yang terdiri dari 25 soal dengan pilihan jawaban a, b, c, d dan e.

Instrumen penelitian hasil belajar terdiri dari dua jenis yaitu penelaian tes akhir dan penilaian proses. Pada penilaian tes akhir, untuk rincian pertanyaan, aspek-aspek yang diukur, format dan prosedur pengembanganya sama seperti dalam pengembangan instrumen kemampuan awal. Perbedaanya hanya terletak pada susunan urutan nomor butir tes yang disajikan.

\section{Teknik Pengumpulan Data}

Data-data tentang variable penelitian untuk kepentingan analisis data dikumpulkan menggunakan teknik pengumpulan data sebagaimana disajikan pada tabel 8.

\section{Tabel 8. Teknik Pengumpulan Data}

\begin{tabular}{cll}
\hline No. & Variabel Penelitian & Teknik Pengumpulan Data \\
\hline 1 & Self-efficacy Komputer & Self-Inventory \\
2 & Motivasi Belajar & Self-Inventory \\
3 & Hasil Belajar Siswa & Tes \\
\hline
\end{tabular}

\section{Tenik Analisis Data}

Data yang telah diperoleh kemudian dianalisis menggunakan SPSS versi 14.0, baik untuk uji asumsi maupun untuk pengujian hipotesis penelitian. Analisis data dilakukan dengan menggunakan metode analisis deskriptif dan analisis infersial. Analisis deskriptif adalah suatu metode penelitian yang bersifat menggambarkan kenyataan atau fakta sesuai dengan data yang diperoleh saat penelitian. Analisis deskriptif disini terikat dengan perbedaan kualitas pembelajaran antara siswa yang diberikan perlakuan menggunakan model pembelajaran web centric course dan pembelajaran konvensional. Sedangkan analisis inferesial disini terikat dengan (1) uji normalitas, (2) uji homogenitas, dan (3) uji hipotesis. 


\section{HASIL}

Sebagaimana telah dijabarkan pada Bab III, penelitian ini menggunakan kelas X RPL C sebagai kelas kontrol dengan perlakuan pembelajaran secara konvensional dilengkapi dengan modul dan kelas X RPL B sebagai kelas eksperimen dengan perlakuan pembelajaran web centric course dilengkapi dengan modul. Jumlah subjek pada kelas X RPL B sebanyak 33 siswa, dan pada kelas X RPL C sebanyak 33 siswa. Deskripsi umum hasil penelitian meliputi deskripsi hasil belajar, deskripsi motivasi belajar, dan deskripsi self efficacy komputer akan diuraikan secara ringkas, pembahasan selengkapnya disajikan dalam lampiran tentang deskripsi hasil penelitian.

\section{Deskripsi Statistik Hasil Belajar Berdasarkan Jenis Perlakuan dalam Kelompok}

Deskripsi statistik hasil belajar Pemrograman Dasar antara kelompok siswa yang diajar dengan model pembelajaran Web Centric Course dilengkapi dengan modul dengan siswa yang diajar dengan model pembelajaran konvensional dilengkapi modul tanpa memperhatikan tingkat motivasi belajar dan self efficacy komputer disajikan pada tabel 9.

Tabel 9. Deskripsi Statistik Hasil Belajar Pemrograman Dasar Berdasarkan Jenis Perlakuan dalam kelompok

\begin{tabular}{cllll}
\hline No & \multicolumn{1}{c}{ Kelompok Perlakuan } & Rerata & SD & N \\
\hline 1 & Web Centric Course dilengkapi dengan Modul & 84.77 & 9,024 & 33 \\
2 & Konvensional dilengkapi dengan Modul & 82,79 & 6,289 & 33 \\
\hline
\end{tabular}

Pada tabel tersebut dapat ditunjukkan bahwa rerata hasil belajar siswa pada kelompok Web Centric Course dilengkapi dengan modul adalah 84,77 lebih tinggi daripada rerata hasil belajar kelompok siswa yang mendapatkan pembelajaran secara konvensional dengan rerata sebesar 82,79.

\section{Deskripsi Hasil Belajar Siswa Berdasarkan Motivasi Belajar}

Berdasarkan skor motivasi belajar diperoleh data bahwa perbedaan tingkat motivasi belajar yaitu tingkat tinggi dan rendah. Siswa digolongkan kedalam kelompok siswa dengan motivasi belajar tinggi apabila nilai instrumen motivasi yang diperoleh lebih tinggi atau sama dengan median ( $\geq$ median), sedangkan kelompok siswa dengan motivasi belajar rendah apabila nilai instrumen motivasi yang diperoleh lebih kecil dari nilai median (< median).

Pada kelompok siswa yang diberikan model pembelajaran Web Centric Course dilengkapi dengan modul yaitu kelas $\mathrm{X}$ RPL B, dari 33 siswa yang mempunyai motivasi belajar tinggi berjumlah 14 siswa dan siswa yang mempunyai motivasi belajar rendah berjumlah 19 siswa. Pada kelompok siswa yang diberikan pembelajaran konvensional dilengkapi dengan modul yaitu kelas X RPL C dengan jumlah siswa sebanyak 33 siswa. Siswa yang mempunyai motivasi belajar tinggi berjumlah 15 siswa, dan siswa yang mempunyai motivasi belajar rendah berjumlah 18 siswa. Deskripsi statistik hasil belajar Pemrograman Dasar berdasarkan tingkat motivasi belajar pada masing-masing kelompok disajikan pada tabel 10.

Tabel 10. Deskripsi Hasil Belajar Berdasarkan Tingkat Motivasi Belajar

\begin{tabular}{llllll}
\hline NO & Kelompok Perlakuan & Kelompok Motivasi Belajar & Rerata & SD & N \\
\hline 1 & Web Centric Course dilengkapi dengan Modul & Rendah & 79,20 & 7,768 & 19 \\
& & Tinggi & 92,33 & 3,158 & 14 \\
& & & & & \\
2 & \multirow{2}{*}{ Konvensional dilengkapi dengan Modul } & Rendah & 78,55 & 4,706 & 18 \\
& & Tinggi & 87,87 & 3,571 & 15 \\
\hline
\end{tabular}

Pada tabel di atas dapat dilihat bahwa siswa yang mempunyai motivasi belajar tinggi memperoleh hasil belajar lebih tinggi dibandingkan dengan hasil belajar siswa yang mempunyai motivasi belajar rendah baik pada kelompok perlakuan pembelajaran Web Centric Course dilengkapi dengan modul maupun pada pembelajaran konvensional dilengkapi dengan modul.

\section{Deskripsi Hasil Belajar Berdasarkan Tingkatan Self Efficacy Komputer}

Berdasarkan skor instrumen self efficacy komputer diperoleh data self efficacy komputer rendah dan tinggi. Siswa dikelompokkan kedalam kelompok siswa dengan self efficacy komputer tinggi apabila nilai instrumen yang diperoleh lebih tinggi atau sama dengan median ( $\geq$ median), sedangkan apabila nilai instrumen yang diperoleh lebih kecil dari nilai median ( $<$ median) maka digolongkan self efficacy komputer rendah. 
Dari 33 siswa pada kelompok pembelajaran Web Centric Course dilengkapi dengan modul, diperoleh data siswa yang mempunyai self efficacy komputer rendah berjumlah 18 siswa sedangkan siswa yang mempunyai self efficacy komputer tinggi berjumlah 15 siswa. Pada kelompok pembelajaran konvensional dilengkapi dengan modul, diperoleh data siswa yang mempunyai self efficacy komputer rendah berjumlah 14 siswa, sedangkan siswa yang mempunyai self efficacy komputer tinggi berjumlah 19 siswa. Deskripsi hasil belajar siswa Pemrograman Dasar berdasarkan tingkat self efficacy komputer pada masingmasing kelompok disajikan pada tabel 11 .

Tabel 11. Deskripsi Hasil Belajar Berdasarkan Tingkat Self Efficacy Komputer

\begin{tabular}{llllll}
\hline No. & Kelompok Perlakuan & Kelompok Self Efficacy Komputer & Rerata & SD & N \\
\hline 1 & Web Centric Course dilengkapi dengan modul & Rendah & 77,47 & 7,901 & 15 \\
& & Tinggi & 90,85 & 3,973 & 18 \\
& & & & & \\
2 & \multirow{2}{*}{ Konvensional dilengkapi dengan modul } & Rendah & 77,29 & 4,605 & 14 \\
& & Tinggi & 86,84 & 3,764 & 19 \\
\hline
\end{tabular}

Pada tabel diatas diketahui bahwa siswa yang memiliki self efficacy komputer tinggi memperoleh hasil belajar lebih tinggi/lebih baik dibandingkan siswa yang memiliki self efficacy komputer rendah baik pada kelompok pembelajaran Web Centric Course dilengkapi dengan modul, maupun kelompok pembelajaran konvensional dilengkapi dengan modul.

\section{Pengujian Hipotesis}

Hipotesis ke 1, 2 dan 3 pada penelitian ini dianalisis dengan menggunakan Uji Independent Sample T-Test. Sebagaimana diketahui bahwa dalam statistik inferensial parametrik (Uji Beda) terdapat syarat-syarat yang harus terpenuhi sebelum dilakukan yaitu data harus di uji normalitas dan hasilnya harus berdistribusi normal serta data harus sejenis atau homogen. Untuk menguji normalitas data digunakan Uji Normalitas Kolgorov-Smirnov dan untuk mengetahui homogenitas skor/nilai hasil belajar tiap kelompok dilakukan analisis varian Levene's Test of Equality, maka analisis uji beda untuk menguji hipotesis dapat diteruskan. Hasil Uji Normalitas Kolgorov-Smirnov disajikan pada tabel 12.

Pada tabel 12 dapat diketahui bahwa nilai signifikasi sama dengan 0,504 (p>0,05). Hal ini berarti dapat disimpulkan bahwa data yang uji berdistribusi normal. Untuk mengetahui homogenitas skor/nilai hasil belajar tiap kelompok dilakukan analisis varian Levene's Test of Equality. Hasil analisis varians Levene's Test of Equality disajikan pada tabel 13.

Pada tabel 13 dapat diketahui bahwa signifikasi Levene's Test of Equality sama dengan 0,295 (p>0,05). Hal ini berarti bahwa nilai hasil belajar tiap kelompok mempunyai varians yang sama atau homogen sehingga analisis untuk menguji hipotesis dapat dilanjutkan.

Tabel 12. Hasil Uji Normalitas Kolgorov-Smirnov

\begin{tabular}{lll}
\hline & & Unstandardiz ed Residual \\
\hline $\mathrm{N}$ & & 33 \\
Normal Parameter a,b & \multicolumn{1}{c}{ Mean } &, 0000000 \\
\hline & Std. Deviation & 11,15873794 \\
\hline Most Extreme & Absolute &, 144 \\
Defferences & Positive &, 144 \\
& Negative &,- 098 \\
\hline Kolmogorov-Smirnov Z & &, 825 \\
Asymp. Sig. (2-tailed) & &, 504 \\
\hline
\end{tabular}

Tabel 13. Hasil Analisis Varians Levene's Test of Equality

\begin{tabular}{llll}
\hline F & df1 & df2 & Sig. \\
\hline 1,293 & 8 & 23 & 0.295 \\
\hline
\end{tabular}

\section{Pengujian Hipotesis ke-1}

Hipotesis pertama pada penelitian ini adalah: “Adakah perbedaan hasil belajar Pemrograman Dasar yang signifikan antara kelompok siswa yang diajar dengan model pembelajaran Web Centric Course dilengkapi modul dengan kelompok siswa yang diajar dengan model pembelajaran konvensional dilengkapi modul”.

Pengajuan Hipotesis Nol (H0): 
H0: $\mu 1=\mu 2$ atau tidak ada perbedaan hasil belajar disebabkan oleh faktor pertama. Faktor pertama adalah variabel $\mathrm{X}_{1}$ yaitu pemberian perlakuan. Dimana $\mu 1$ adalah rerata hasil belajar kelompok Web Centric Course dilengkapi modul, sedangkan $\mu 2$ adalah rerata hasil belajar kelompok pembelajaran konvensional dilengkapi modul. Ringkasan hasil Uji Independent Sample TTest pada sumber perlakuan disajikan pada tabel 14 .

Kriteria pengujian hipotesis:

Jika probabilitas > 0.05, maka $\mathrm{H} 0$ gagal ditolak

Jika probabilitas $\leq 0.05$, maka $\mathrm{H} 0$ ditolak

Tabel 14. Ringkasan Hasil Pembelajaran Uji Independent Sample T-Test

\begin{tabular}{clccccc}
\hline Source & F & Sig & t & df & Sig. (2-tailed) \\
\hline \multirow{2}{*}{ Hasil Pembelajaran } & Equal variances assumed & 2,421 & 0,125 & 1,034 & 64 & 0,305 \\
\cline { 2 - 7 } & Equal variances not assumed & & & 1,034 & 57,154 & 0,305 \\
\hline
\end{tabular}

Pada tabel 14 dapat diketahui bahwa pada sumber (source) "Hasil_Pembelajaran" dengan derajad kebebasan/Degree of Freedom $(\mathrm{df})=64$; Nilai $\mathrm{F}=2,421$ dengan signifikansi $=0.305$. Besarnya probabilitas/signifikansi lebih dari $0.05(\mathrm{p} \geq 0.05)$ maka H0 gagal ditolak. Sehingga dapat diinterpretasikan bahwa tidak ada perbedaan hasil belajar Pemrograman Dasar yang signifikan antara kelompok siswa yang diajar dengan model pembelajaran Web Centric Course dilengkapi modul dengan kelompok siswa yang diajar dengan model pembelajaran konvensional dilengkapi modul. Tetapi Rerata hasil belajar kelompok siswa yang memperoleh model pembelajaran Web Centric Course dilengkapi modul berbeda secara signifikan dengan rerata hasil belajar kelompok siswa yang memperoleh pembelajaran konvensional dilengkapi modul. Ringkasan rerata hasil belajar karena pemberian perlakuan disajikan pada tabel 15.

Tabel 15. Ringkasan Rerata Hasil Belajar Berdasarkan Perlakuan

\begin{tabular}{lllll}
\hline No. & Kelompok Perlakuan & Rerata & SD & N \\
\hline 1 & Web Centric Course + modul & 84,77 & 9,024 & 33 \\
2 & Konvensional + modul & 82,79 & 6,289 & 33 \\
\hline
\end{tabular}

Pada tabel 15 dapat dilihat bahwa rerata hasil belajar siswa pada kelompok Web Centric Course dilengkapi modul lebih tinggi dengan nilai rerata 84,77 dari rerata hasil belajar siswa pada kelompok konvensional dilengkapi modul dengan nilai rerata 82,79. Berdasarkan perbedaan rerata hasil belajar yang signifikan antara kedua kelompok maka dengan demikian pemberian perlakuan memberikan pengaruh yang signifikan terhadap hasil belajar Pemrograman Dasar kelas X.

\section{Pengujian Hipotesis ke-2}

Hipotesis kedua pada penelitian ini adalah: "Ada perbedaan hasil belajar Pemrograman Dasar yang signifikan antara kelompok siswa yang memiliki motivasi belajar tinggi dengan kelompok siswa yang memiliki motivasi belajar rendah". Pengajuan hipotesis Nol (H0):

H0: $\mu 1=\mu 2$ atau tidak ada perbedaan hasil belajar disebabkan oleh faktor kedua. Faktor kedua adalah variabel $\mathrm{X}_{2}$ yaitu motivasi belajar siswa. Dimana $\mu 1$ adalah rerata hasil belajar kelompok siswa yang mempunyai motivasi belajar rendah, sedangkan $\mu 2$ adalah rerata hasil belajar kelompok siswa yang mempunyai motivasi tinggi. Ringkasan hasil Uji Independent Sample T-Test pada sumber motivasi belajar untuk kelas Experimen disajikan pada tabel 16.

Kriteria pengujian hipotesis:

Jika probabilitas > 0.05, maka $\mathrm{H} 0$ gagal ditolak

Jika probabilitas $\leq 0.05$, maka $\mathrm{H} 0$ ditolak

Tabel 16. Self-Efficacy Komputer Kelas Eksperimen Uji Independent Sample T-Test

\begin{tabular}{clcccc}
\hline Source & t & df & Sig. (2-tailed) & Mean Difference \\
\hline Hasil_Pembelajaran & $\begin{array}{l}\text { Equal variances } \\
\text { assumed }\end{array}$ & $-6,302$ & 31 & 0,000 & $-13,374$ \\
& $\begin{array}{l}\text { Equal variances } \\
\text { not assumed }\end{array}$ & $-5,958$ & 19,797 & 0,000 & $-13,374$ \\
\hline
\end{tabular}


Pada tabel 16 dapat diketahui bahwa pada sumber (source) "Hasil_Pembelajaran" dengan derajad kebebasan/Degree of Freedom $(\mathrm{df})=31$; dengan signifikansi $=0.000$. Besarnya probabilitas/signifikansi kurang dari $0.05(\mathrm{p} \leq 0.05)$, sehingga dapat diinterpretasikan bahwa ada perbedaan hasil belajar Pemrograman Dasar yang signifikan antara kelompok siswa yang memiliki motivasi belajar tinggi dengan kelompok siswa yang memiliki motivasi belajar rendah pada kelas eksperimen. Rerata hasil belajar kelompok siswa yang mempunyai motivasi belajar tinggi berbeda secara signifikan dengan rerata hasil belajar kelompok siswa yang mempunyai motivasi belajar rendah pada kelas eksperimen. Ringkasan hasil Uji Independent Sample T-Test pada sumber motivasi belajar untuk kelas kontrol disajikan pada tabel 17.

Tabel 17. Ringkasan Self-Efficacy Komputer Kelas Kontrol Uji Independent Sample T-Test

\begin{tabular}{clrrrc}
\hline Source & t & df & Sig. (2-tailed) & Mean Difference \\
\hline \multirow{2}{*}{ Hasil Pembelajaran } & Equal variances assumed & $-6,301$ & 31 & 0,000 & $-9,321$ \\
& Equal variances not assumed & $-6,462$ & 30,771 & 0,000 & $-9,321$ \\
\hline
\end{tabular}

Pada tabel 17 dapat diketahui bahwa pada sumber (source) "Hasil Pembelajaran" dengan derajad kebebasan/Degree of Freedom $(\mathrm{df})=31$; dengan signifikansi $=0.000$. Besarnya probabilitas/signifikansi kurang dari 0.05 ( $\mathrm{p} \leq 0.05)$ sehingga dapat diinterpretasikan bahwa ada perbedaan hasil belajar Pemrograman Dasar yang signifikan antara kelompok siswa yang memiliki motivasi belajar tinggi dengan kelompok siswa yang memiliki motivasi belajar rendah pada kelas kontrol. Rerata hasil belajar kelompok siswa yang mempunyai motivasi belajar tinggi berbeda secara signifikan dengan rerata hasil belajar kelompok siswa yang mempunyai motivasi belajar rendah pada kelas kontrol.

Faktor perlakuan dan faktor motivasi belajar terhadap hasil belajar dalam masing-masing kelompok perlakuan dapat diketahui hasilnya seperti disajikan pada tabel berikut tentang rerata hasil belajar pada kedua kelompok yaitu kelompok Web Centric Course dilengkapi modul dan pada kelompok konvensional dilengkapi modul. Ringkasan rerata hasil belajar karena motivasi belajar disajikan pada tabel 18 .

Tabel 18. Ringkasan Rerata Hasil Belajar Berdasarkan Motivasi Belajar

\begin{tabular}{cclll}
\hline No. & Kelompok Perlakuan & Motivasi Belajar & Rerata & N \\
\hline \multirow{2}{*}{1} & \multirow{2}{*}{ Web Centric Course + modul } & Rendah & 79,20 & 19 \\
& & Tinggi & 92,33 & 14 \\
\hline \multirow{2}{*}{2} & \multirow{2}{*}{ Konvensional + modul } & Rendah & 78,55 & 18 \\
& & Tinggi & 87,87 & 15 \\
\hline
\end{tabular}

Pada tabel 18 dapat dilihat bahwa rerata hasil belajar siswa pada kelompok Web Centric Course dilengkapi modul yang memiliki motivasi belajar tinggi dengan nilai rerata 92,33 lebih tinggi dari siswa yang memiliki motivasi belajar rendah dengan nilai rerata 79,20. Sedangkan rerata hasil belajar siswa pada kelompok konvensional dilengkapi modul yang memiliki motivasi belajar tinggi dengan nilai rerata 87,87 lebih tinggi dari siswa yang memiliki motivasi belajar rendah dengan nilai rerata 78,55 .

Berdasarkan perbedaan rerata hasil belajar yang signifikan atara kedua kelompok dengan melihat motivasi belajar siswa maka dapat disimpulkan bahwa siswa yang memiliki motivasi belajar tinggi memperoleh hasil belajar yang lebih baik dibandingkan dengan siswa yang memiliki motivasi belajar rendah pada semua kelompok baik kelompok Web Centric Course dilengkapi modul dan kelompok konvensional dilengkapi modul. Dengan demikian dapat diinterpretasikan bahwa hasil belajar Pemrograman Dasar dapat dijelaskan oleh variasi tingkat motivasi belajar siswa.

\section{Pengujian Hipotesis ke-3}

Hipotesis ketiga dalam penelitian ini adalah: “Ada perbedaan hasil belajar Pemrograman Dasar yang signifikan antara kelompok siswa yang memiliki Self Efficacy komputer tinggi dengan kelompok siswa yang memiliki Self Efficacy komputer rendah"

Pengajuan hipotesis Nol (H0):

H0: $\mu 1=\mu 2$ atau tidak ada perbedaan hasil belajar disebabkan oleh faktor ketiga. Faktor ketiga adalah variabel $\mathrm{X}_{3}$ yaitu Self Efficacy komputer siswa. Dimana $\mu 1$ adalah rerata hasil belajar kelompok siswa yang mempunyai Self Efficacy komputer rendah, sedangkan $\mu 2$ adalah rerata hasil belajar kelompok siswa yang mempunyai Self Efficacy komputer tinggi. Hasil Uji Independent Sample T-Test pada sumber Self Efficacy Komputer untuk kelas kontrol disajikan pada tabel 19.

Kriteria pengujian hipotesis:

Jika probabilitas $>0.05$, maka H0 gagal ditolak

Jika probabilitas $\leq 0.05$, maka H0 ditolak 
Tabel 19. Self-Efficacy Komputer Kelas Eksperimen Uji Independent Sample T-Test

\begin{tabular}{clcccc}
\hline Source & t & df & Sig. (2-tailed) & Mean Difference \\
\hline Hasil Pembelajaran & $\begin{array}{l}\text { Equal variances } \\
\text { assumed }\end{array}$ & $-6,302$ & 31 & 0,000 & $-13,374$ \\
& $\begin{array}{l}\text { Equal variances not } \\
\text { assumed }\end{array}$ & $-5,958$ & 19,797 & 0,000 & $-13,374$ \\
& & & &
\end{tabular}

Pada tabel 19 dapat diketahui bahwa pada sumber (source) "Self Efficacy Komputer" dengan derajad kebebasan/Degree of Freedom $(\mathrm{df})=31$; dengan signifikansi $=0,000$. Besarnya probabilitas/signifikansi kurang dari 0.05 $(\mathrm{p} \leq 0.05)$, sehingga dapat diinterpretasikan bahwa ada perbedaan hasil belajar Pemrograman Dasar yang signifikan antara kelompok siswa yang memiliki Self Efficacy Komputer tinggi dengan kelompok siswa yang memiliki Self Efficacy Komputer rendah pada kelas eksperimen. Ringkasan hasil Uji Independent Sample T-Test pada sumber Self Efficacy Komputer untuk kelas kontrol disajikan pada tabel 20.

Tabel 20. Self-Efficacy Komputer Kelas Kontrol Uji Independent Sample T-Test

\begin{tabular}{cllrrc}
\hline \multicolumn{1}{c}{ Source } & \multicolumn{1}{c}{ t } & df & Sig. (2-tailed) & Mean Difference \\
\hline Hasil Pembelajaran & $\begin{array}{l}\text { Equal variances } \\
\text { assumed }\end{array}$ & $-6,553$ & 31 & 0,000 & $-9,550$ \\
& $\begin{array}{l}\text { Equal variances not } \\
\text { assumed }\end{array}$ & $-5,352$ & 24,639 & 0,000 & $-9,550$ \\
\hline
\end{tabular}

Pada tabel 20 dapat diketahui bahwa pada sumber (source) "Self Efficacy Komputer" dengan derajad kebebasan/Degree of Freedom $(\mathrm{df})=31$; dengan signifikansi $=0,000$. Besarnya probabilitas/signifikansi kurang dari 0.05 $(\mathrm{p} \leq 0.05)$, sehingga dapat diinterpretasikan bahwa ada perbedaan hasil belajar Pemrograman Dasar yang signifikan antara kelompok siswa yang memiliki Self Efficacy Komputer tinggi dengan kelompok siswa yang memiliki Self Efficacy Komputer rendah pada kelas kontrol.

Faktor perlakuan dan faktor Self Efficacy Komputer terhadap hasil belajar dalam masing-masing kelompok perlakuan dapat diketahui hasil analisis varian seperti disajikan pada tabel dibawah tentang rerata hasil belajar pada kedua kelompok yaitu kelompok Web Centric Course dilengkapi modul dan pada kelompok konvensional dilengkapi modul. Ringkasan rerata hasil belajar berdasarkan Self Efficacy Komputer disajikan pada tabel 21.

Tabel 21. Ringkasan Rerata Hasil Belajar Berdasarkan Self Efficacy Komputer

\begin{tabular}{lllll}
\hline No. & Kelompok Perlakuan & Self Efficacy Komputer & Rerata & N \\
\hline 1 & Web Centric Course + modul & Rendah & 77,47 & 15 \\
& & Tinggi & 90,85 & 18 \\
\multirow{2}{*}{2} & \multirow{2}{*}{ Konvensional + modul } & Rendah & 77,29 & 14 \\
& & Tinggi & 86,84 & 19 \\
\hline
\end{tabular}

Pada tabel 21 dapat dilihat bahwa rerata hasil belajar siswa pada kelompok Web Centric Course dilengkapi modul yang memiliki Self Efficacy Komputer tinggi dengan nilai rerata 90,85 lebih tinggi dari siswa yang memiliki Self Efficacy Komputer rendah dengan nilai rerata 77,47. Sementara itu, rerata hasil belajar siswa pada kelompok konvensional dilengkapi modul yang memiliki Self Efficacy Komputer tinggi dengan nilai rerata 86,84 juga lebih tinggi dari siswa yang memiliki Self Efficacy Komputer rendah dengan nilai rerata 77,29. Berdasarkan perbedaan rerata hasil belajar yang signifikan atara kedua kelompok dengan melihat Self Efficacy Komputer siswa maka dapat disimpulkan bahwa siswa yang memiliki Self Efficacy Komputer tinggi memperoleh hasil belajar yang lebih baik dibandingkan dengan siswa yang memiliki Self Efficacy Komputer rendah pada semua kelompok baik kelompok Web Centric Course dilengkapi modul dan kelompok konvensional dilengkapi modul. Dengan demikian dapat diinterpretasikan bahwa hasil belajar Pemrograman Dasar dapat dijelaskan oleh variasi tingkat Self Efficacy Komputer siswa. 


\section{SIMPULAN}

Ada perbedaan hasil belajar Pemrograman Dasar yang signifikan antara kelompok siswa yang diajar dengan Web Centric Course dilengkapi modul dengan kelompok siswa yang diajar dengan pembelajaran konvensional dilengkapi modul. Rerata hasil belajar Pemrograman Dasar kelompok Web Centric Course dilengkapi modul adalah 84,77 lebih tinggi dari rerata hasil belajar Pemrograman Dasar kelompok konvensional dilengkapi modul dengan rerata nilai 82,79. Pemberian perlakuan Web Centric Course dilengkapi modul memberikan dampak yang lebih baik dibandingkan dengan model pembelajaran konvensional dilengkapi modul.

Ada perbedaan hasil belajar Pemrograman Dasar yang signifikan antara kelompok siswa yang memiliki motivasi belajar tinggi dengan kelompok siswa yang memiliki motivasi belajar rendah. Rerata hasil belajar Pemrograman Dasar siswa yang memiliki motivasi belajar tinggi pada kelompok Web Centric Course dilengkapi modul adalah 92,33 lebih tinggi dari rerata hasil belajar Pemrograman Dasar siswa yang memiliki motivasi belajar rendah dengan rerata nilai sebesar 79,20. Rerata hasil belajar Pemrograman Dasar siswa yang memiliki motivasi belajar tinggi pada kelompok konvensional dilengkapi modul adalah 87,87 lebih tinggi dari rerata hasil belajar Pemrograman Dasar siswa yang memiliki motivasi belajar rendah dengan rerata nilai 78,55 .

Ada perbedaan hasil belajar Pemrograman Dasar yang signifikan antara kelompok siswa yang memiliki Self Efficacy komputer tinggi dengan kelompok siswa yang memiliki Self Efficacy komputer rendah. Rerata hasil belajar siswa yang memiliki Self Efficacy komputer tinggi pada kelompok Web Centric Course dilengkapi modul adalah 90,85 lebih tinggi dari rerata hasil belajar Pemrograman Dasar siswa yang memiliki Self Efficacy komputer rendah dengan rerata nilai 77,47. Sementara itu, rerata hasil belajar siswa yang memiliki Self Efficacy komputer tinggi pada kelompok konvensional dilengkapi modul adalah 86,84 lebih tinggi dari rerata hasil belajar siswa yang memiliki Self Efficacy komputer rendah dengan rerata nilai 77,29.

\section{DAFTAR RUJUKAN}

Azwar, S. (2013). Sikap Manusia: Teori dan Pengukurannya. In Sikap Manusia: Teori dan Pengukurannya. https://doi.org/10.1038/cddis.2011.1

Cassidy, S., \& Eachus, P. (2002). Developing the Computer User Self-Efficacy (CUSE) Scale: Investigating the Relationship between Computer Self-Efficacy, Gender and Experience with Computers. Journal of Educational Computing Research. https://doi.org/10.2190/JGJR-0KVL-HRF7-GCNV

Dimyati \& Mudjiono. (2006). Hakikat Belajar dan Pembelajaran. Jakarta: Gramedia Pustaka Utama.

Durndell, A., Haag, Z., \& Laithwaite, H. (2000). Computer Self Efficacy and Gender: A Cross Cultural Study of Scotland and Romania. Personality and Individual Differences. https://doi.org/10.1016/S0191-8869(99)00155-5

Hermawan, T. (2013). Keefektifan Pembelajaran Berbasis WEB untuk Meningkatkan Motivasi Belajar Mahasiswa Teknologi Pendidikan. Skripsi tidak diterbitkan. Universitas Negeri Semarang, Semarang.

Nurhikmah, H. Hakim, A., Muin, A., Hartoto., \& Ramli, A. M. (2010). Perbandingan Hasil Belajar dengan menggunakan Model Pembelajaran berbasis Internet Web Centric Course dan Model Pembelajaran Konvensional pada Mahasiswa yang Memiliki Tingkat Self-Efficacy Kemampuan Komputer Berbeda. International Conference on Education Technology. Advances in Social Science, Education and Humanities Research, volume 372

Pratiwi, Y. R., Mukhadis, A., \& Sukarni. (2010). Pengaruh Metode Student Teams Achievement Divisions (STAD) dan Motivasi Berprestasi terhadap Hasil Belajar Bidang Studi Sistem Pemindah Tenaga. Jurnal Teknologi, Kejuruan dan Pengajarannya, 3(2), 151-161.

Sam, H. K., Othman, A. E. A., \& Nordin, Z. S. (2005). Computer Self-Efficacy, Computer Anxiety, and Attitudes Toward the Internet: A Study among Undergraduates in Unimas. Educational Technology and Society.

Singh, H. (2003). Building Effective Blended Learning Programs. Educational Technology: The Magazine for Managers of Change in Education.

Widiarti, E. (2018). Pengaruh Motivasi Belajar dan Kesiapan Belajar Siswa terhadap Hasil Belajar Mata Pelajaran Ekonomi Siswa Kelas X Ilmu-Ilmu Sosial di SMA Negeri 2 Banguntapan. Jurnal Pendidikan Ekonomi, 7(4), 298-305.

Widiyanto, A. (2013). Pengaruh Self-Efficacy dan Motivasi Berprestasi Siswa terhadap Kemandirian Belajar Mata Pelajaran Keselamatan dan Kesehatan Kerja (K3). Jurnal Pendidikan Teknik Elektro, 1-10. 